\title{
TERRITORIAL INEQUALITY AND SPATIAL JUSTICE. HOW LEVEL IS THE SUSTAINABLE DEVELOPMENT PLAYING FIELD?
}

\author{
Alys Solly \\ Interuniversity Department of Regional and Urban Studies and Planning, Politecnico di Torino \\ Viale Pier Andrea Mattioli, 39, 10125 Turin: Italy \\ alys.solly@polito.it
}

\begin{abstract}
Currently, inequality levels are on the rise although the spatial dimension of social, economic and environmental justice is also gaining prominence. At the same time, progressive institutional changes are underway in many cities and regions. This paper looks at these paradigm shifts through the lenses of sustainable well-being and of spatial justice. It also reflects on the concepts of territorial disparity and scarcity of resources, as well as on the challenges of assessing spatial justice. Finally, the paper discusses the role of spatial planning in tackling these issues, in the light of current approaches to sustainable development such as the circular economy.
\end{abstract}

Keywords: inequality, spatial justice, sustainable development, well-being.

\section{Introduction}

Local communities are facing new challenges, such as climate change, population increase and energy consumption, which are leading to growing social inequalities. Yet, although current consumption patterns may exacerbate existing inequalities, emerging networks may give rise to institutional change and the promotion of social equality and environmental justice (Carmin \& Agyeman, 2011). This is evident in the emphasis currently attributed to working through new scales of governance and the emergence of 'soft spaces' (Allmendinger, Haughton, Knieling \& Othengrafen, 2015). In fact, these new approaches, with their flexible and innovative nature, might well trigger increased demand for more equitable development, which needs to be addressed by spatial planning. Indeed, spatial planning is an eminently distributive activity (Moroni, 2010), which aims to ensure that public decisions are taken in an equitable way and provide positive outcomes for all of the involved stakeholders (Carmona \& Sieh, 2004, p. 38). Nevertheless, there is often a lack of equity in the distribution of resources, leading to inequality and social exclusion. As a consequence, spatial planning has been criticized for not facing its tasks in an effective way, such as achieving a more conscious and sustainable use of natural resources and the reduction of socio-economic inequalities. ${ }^{1}$ In fact, ' with ineffective planning, lack of civic participation, and

1 The Territorial Agenda 2030 published on 1 December 2020 by the Informal meeting of EU Ministers responsible for Spatial Planning and Territorial Development and/or Territorial Cohesion draws attention to the spatial dimension of the widening social and economic disparities in Europe, as highlighted in the 'geography of 
neglect of social equity, cities can become deeply divided' (Sachs, 2015, p. 367). On the contrary, effective planning can strengthen public involvement in political decisions, enhancing social inclusion. This paper suggests that in order to overcome these challenges, it is important to better integrate these issues into urban policies and projects.

The concepts of spatial equity and territorial (in)equality should therefore be central to spatial planning and this paper examines them through the lens of well-being. It is divided into three main parts. The first looks at the spatial and territorial dimension of (in)equality, focusing on the issues of territorial disparity and scarcity of resources, as well as on some possible ways of regulating these territorial (in)equalities. The second considers some of the current challenges of assessing spatial (in)equality and discusses the paradigm shift towards sustainable well-being and spatial justice, taking into consideration the concept of circular economy and also looking at new responses to climate change challenges, such as managed retreat. The third part reflects on the role of spatial planning in dealing with these issues, with some case study exemplification. A number of final considerations and possible future research avenues are then presented.

\section{Methodological approach and data}

The article starts from the premise that a knowledge gap exists in the current discussion on sustainable development, in relation to territorial inequality and spatial justice, and that the scientific and planning environment needs to carry out further in-depth research on these issues. The paper therefore provides an overview and analysis of the current state of the art and the evolution underway, using the lens of sustainable and equitable well-being to look at the principles underpinning a balanced and long-term sustainable development. It focuses on the challenges of achieving spatial equality and justice, highlighting the role of current spatial planning approaches in tackling inequality, and addresses the following research questions:

- How level is the sustainable development playing field?

- How can sustainable development and spatial (in)equality be accurately assessed?

- How can the role of spatial planning be improved to better promote sustainable development, but at the same time reduce inequalities?

The paper builds on information and data deriving from scientific publications, and refers to globally available statistical data, such as GDP and Gini surveys, in order to explore the issues. For example, it assesses the extent of spatial (in)equality, illustrating the geographical coverage of the Gini index, through selected application of the ArcGIS (Geographic Information System) and analysis of Eurostat and World Bank data. A number of case studies are referred to, in order to present and exemplify the situation as regards spatial differentiation in access to resources in various countries and contexts (including South Africa and the United Kingdom). The paper aims to set in motion further more specific comparative research on the relationship(s) between spatial justice and sustainable development. It also suggests that there could well be an important role for spatial planning in relation to meeting new climate change challenges, which is necessary to explore and which could have implications for spatial justice.

discontent' debate. The Agenda declares that the underlying objective of all public policies should be to increase citizens' well-being and quality of life, observing: 'these go beyond economic performance, living standards and purely material aspects [and] also have a territorial dimension ranging from disparities between neighbourhoods such as social exclusion and urban poverty, to disparities between regions and countries' (TA2030, 2020, p. 7). 


\section{Territorial disparities, scarcity of resources and the regulation of spatial inequality}

In the last decades, social and economic inequality levels have grown in many countries (Piketty, 2014; Milanovic, 2016). Urbanization levels have also grown and, by 2050, $70 \%$ of the world's population is projected to be living in urban areas (OECD, 2012). Large parts of the population have moved from rural towards urban areas, intensifying rural-urban migration trajectories. Currently, the urban population is increasing faster in less-developed countries than in more-developed ones. These migration processes have also led to an increase in urban population density, leading policy-makers to face new social and economic challenges. Ahlfeldt and Pietrostefani (2019) have examined how population density influences inequality levels in urban areas, and suggest that, even though densely populated cities have a certain number of benefits (e.g. public services), they also lead to higher levels of inequality (e.g. expensive housing). It is, furthermore, important to highlight that inequality is typically associated with lower levels of citizens' happiness (Buttrick, Heinzelman \& Oishi, 2017). Moreover, it seems that 'countries with better government register lower levels of spatial inequality' (Ezcurra \& Rodríguez-Pose, 2014, p. 1732) and higher levels of quality of life $(\mathrm{Q} o \mathrm{~L})$. For these reasons, the principle of spatial (in)equality has received increasing attention from academics, as well as from policy and decision makers. At an international level, the importance of the concept of inequality was reiterated in 2015 by the United Nations (UN), with its publication of the 17 Sustainable Development Goals (SDGs). In particular, SDG 10 aims to 'reduce inequality within and among countries' (UN, 2015, p. 14). It is, therefore, important to look at the spatial dimension of inequality, focusing on the quality of territorial governance, as well as at the institutional mechanisms that may trigger more equitable policies and projects (e.g. through increased public participation and transparency).

Beramendi (2007) points out that even though research has shown that decentralized political structures have often led to higher levels of inequality, as well as to lower levels of redistribution, the distributive effects of decentralization mainly depend on the pre-existing territorial patterns of inequality. In fact, it seems that existing territorial disparities have 'always been critical to the shaping of inequality' (Sellers, 2017, p. 1). Regional disparities also seem to lead to conflict over the territorial distribution of resources, weakening the political, economic and social stability ( $\varnothing$ stby, Nordrås \& Rød, 2009). As regards conflict, Scheidel (2018, p. 9) observes that, 'from antiquity to the present, land reform has tended to reduce inequality most when associated with violence or the threat of violence'. This is the case of the Western Balkans, which are characterised by a high level of diversity and territorial fragmentation, due to various political, economic, social and cultural reasons. ${ }^{2}$ Today, the Western Balkan region is still perceived as a 'divided region' (Osbild \& Bartlett, 2019, p. 1). On the other hand, a good institutional framework seems to contribute to reducing territorial fragmentation, as well as promoting territorial cohesion and sustainable development (see e.g. Berisha, Cotella \& Solly, forthcoming). Indeed, the notion of quality of institutions 'has emerged as a key aspect of territorial governance' (Pere \& Bartlett, 2019, p. 75). Although, as regards certain aspects of good governance and the rule of law, the situation in the Western Balkans currently appears to lag behind; it could 'improve or worsen depending on what decisions are taken' (Čeperković \& Gaub, 2018, p. 20). Thus, a direct relation seems to exist between territorial disparities and inequality levels: this also links to an important aspect that needs to be further investigated, namely the concept of resource efficiency (discussed later in this paper).

\footnotetext{
${ }^{2}$ According to Ganić (2019, p. 61), growing social and economic inequalities have been a major concern that has accompanied the economic and political transformation of the Western Balkans since the 1990s.
} 
Various administrative organisations find it difficult to meet complex challenges also due to a shortage of resources, which raises doubts as regards the effectiveness of policies oriented primarily towards development, growth and social inequalities. Likewise, possible solutions to a number of common critical topics like sprawl reduction and mixed-use development are still being trialled by policy and decision makers in many European countries (e.g. the adoption of the 30 hectares target in Germany). This can be seen, for example, in the results presented by the recent ESPON SUPER project (Sustainable Urbanization and Land-Use Practices in European Regions) that build on the analysis of more than two hundred examples of urbanization interventions gathered all over Europe. ${ }^{3}$ According to ESPON SUPER (2020), a number of economic programmes have been used, directly or indirectly, to promote fair, equal and balanced land use practices throughout Europe (e.g. the 22@Barcelona programme in Spain, the re-creation of Lake Karla in Thessaly in Greece, the Enjoy Waltham Forest programme in the UK, the BENE - Berlin Programme on Sustainable Development in Germany).

However, even in situations where there is economic growth, local stakeholders often have to deal with complex bureaucratic situations and with pre-used plots, with challenging repercussions on the aims of the development patterns as regards the provision of amenities by the urban ecosystem in order to improve people's well-being, also in terms of their QoL. Indeed, poor allocation of amenities can lead to a loss of subjective well-being. Due to global changes and the inefficient reallocation of resources, many urban ecosystems are unable to provide the services which lead us to adapt to those changes. Such adaptations also imply costs which range from concrete payments to sociological events with a potentially heavy psychological impact, as for example being forced to migrate (Grünberger \& Omann, 2011, p. 7).

\section{Regulating land use}

Land use regulations should also aim to improve the attractiveness of communities and the well-being of their inhabitants; however, binding regulations often have additional indirect effects and can cause unplanned inequalities and inefficiencies. These inefficiencies can also lead to a lower standard of living and may have negative side-effects on productivity. However, Quigley and Rosenthal (2005, p. 76) observe that with the growth of land use regulation, the fiscal externalities governing land use might have increased in importance instead of the physical externalities which originally led to the introduction of zoning in the first place. Yet, they also note that the 'variety of local land use enactments makes it difficult to untangle the link between regulation and its economic effects' (2005, p. 72) and planners may not seek enough efficiency in resource allocation. Brueckner (2006, p. 24-25) argues that 'well-meaning interventions that cause land-use outcomes to diverge substantially from free-market outcomes run the risk of generating net social losses [whereas government interventions intended to steer development] rather than diverting it from a free market path are likely to be socially beneficial'. Moreover, interventions by governments are useful when the aim is to promote optimal urban development. For Quigley and Rosenthal (2005, p. 77), for example, zoning is a 'mechanism that permits a stable equilibrium in residential patterns and can promote efficiency in the urban region'. Since the aim of zoning is to limit negative exter-

\footnotetext{
${ }^{3}$ The ESPON SUPER project's recent (2020) 'Guide to Sustainable Urbanisation and Land-Use' proposes a set of policy recommendations to help policy and decision makers to address land use in a more sustainable perspective and contribute to a more equal, balanced and sustainable territorial development. In particular, the Guide explains that policy and decision makers should focus more on: i) which intervention should be used (i.e. containment, densification, regeneration, governance and sectoral policies) and ii) which instrument (i.e. strategies and visions, rules and legal devices, land use regulations, programmes and projects). Yet, the Guide warns that plans, projects and regulations must be opportunely designed or they might amplify inequalities, producing side-effects like increasing gentrification and segregation issues.
} 
nalities by distinguishing different land uses it is usually considered beneficial. However, Brueckner $(2006$, p. 25) suggests that to 'avoid creating artificial scarcities, such zoning laws must respond to market forces in determining the overall allocation of land to residential, commercial and industrial uses'. Therefore, land use planning can be considered as a kind of regulation as it determines the use of an economic resource according to specific norms and rules. Indeed, planning decisions can intervene and regulate the influence of prices and markets (Cheshire \& Vermeulen, 2009, p. 151). The benefits of land use regulation are evident when it enables market failure to be corrected and the supply of amenities which might otherwise be insufficient to be guaranteed, even though it may restrict the supply of some other valuable goods. Ihlanfeldt (2005, p. 4), observes that 'where land use regulation is more restrictive, there may be less sprawl, a more desirable mix of land uses, and less congestion of public infrastructure'.

\section{Assessing spatial (in)equality, taking into account well-being and spatial justice}

Economists have tended to base their analyses of prosperity on assessments of a nation's Gross Domestic Product (GDP). However, in recent years GDP has come under criticism and there is an important ongoing current debate on the correctness of using GDP data in order to evaluate a country's economic performance. Governments are also trying to improve the accuracy and effectiveness of statistics based on GDP, for, even though it is a commonly used and widely recognised indicator of economic prosperity, it is far from being unproblematic. In fact, GDP is not a complete measure of economic activity and does not show differences in the cost of living and the inflation rates in the countries. Thus, even if the average income of a country or part of a country is rising, the majority of the population might in actual fact be actually worse off in real terms (Stiglitz, Sen \& Fitoussi, 2009, p. 8). Research carried out by the $\operatorname{OECD~}(2014$, p. 1) also shows that when 'income inequality rises, economic growth falls', highlighting the need to better address inequality issues in order to make 'our societies fairer and our economies stronger'. As a result, scholars have emphasised the need to broaden the analysis to take into consideration a wider spectrum of aspects to measure QoL and inequality.

Grünberger and Omann (2011, p. 2) see the reappearance of the concept of QoL in Europe and the United States in the late twentieth century as likely linked to the increasing evidence that a high QoL is not necessarily guaranteed by material wealth. Indeed, the Report by the Commission on the Measurement of Economic Performance and Social Progress (Stiglitz et al., 2009, p. 12) declared as its 'key message and unifying theme [that] it is time for our measurement system to shift the emphasis from measuring economic production to measuring people's well-being [which should be put in a] context of sustainability'. Because there seems to be an increasingly net distinction between the information provided in aggregate GDP data and what is considered the well-being of common people, this focus on the role of well-being is worth noting. Indeed, the interconnectedness of well-being and sustainability and the need for the two to be aligned in policy-making has played a key role in the UN discourse on sustainability since the 1980s. The need to focus more on well-being is stressed by the UN Agenda 2030 (2015). In fact, 'good health and well-being' is goal 3 of the SDGs, which is strongly related to: economic and social inequalities (SDG 10), sustainable urbanization processes (SDG 11), as well as the threats to the climate and the environment (SDG 13). 


\section{Gini index}

The Gini coefficient, also known as the Gini index, is a statistical measure of income inequality. The Gini coefficient varies between 0 , which indicates a complete equal society, and 1 , which denotes a complete unequal society. It provides useful and interesting data which has thrown light on and transformed the assessment of economic, social and political change, also from a historical stance. Indeed, according to Scheidel (2018, p. 15), for example, Gini coefficients can also be applied to the study of material inequality in ancient times.

Today, there is considerable variation in income inequality across the world's countries, especially in some developing countries. In the 1990s, Arrow, Cline, Mäler, Munasinghe and Stiglitz (1995, p. 21) pointed out that many of the 'attempts to improve overall welfare through NorthSouth transfers [were strongly restricted by the principle that] each country tends to consider primarily the welfare of its own citizens, and only secondarily that of others'. ${ }^{4}$ These issues are still very up-to-date and, currently, sharp inequality levels still exist between countries, highlighting this North-South division. Figure 1 shows the Gini coefficient in the various countries: the lighter colours illustrate countries with lower values (thus, a lower level of inequality), whereas the darker colours indicate countries with higher values (thus, a higher level of inequality). Inequality as measured by the Gini coefficient are highest in Global South countries, such as in South Africa (63.0), Namibia (59.1) and Suriname (57.6). However, the coefficient indicates high levels of inequality also in highly developed countries, such as in the United States (41.4) and Israel (39.0). Thus, it can be seen that many problems of unaddressed poverty and social exclusion still exist in many countries in the Global North.

In the last decades, inequality levels have risen in Europe. According to the OECD (2015, April 26, p. 4), "between the mid-90s and the late 2000s, OECD countries experienced a form of 'inequality convergence', with marked and opposite-sign changes in overall disposable income inequality for the most and the least unequal countries". As can be observed in figures 2 and 3 below, the spatial extent of income inequality is heterogeneous, highlighting a high territorial and social fragmentation. In particular, inequality levels seem to have increased in some of the Nordic countries, such as in Denmark and Sweden; nevertheless, their levels of equality and social inclusion are still above the EU average.

Smith (2020, February 3) observes that the Gini index can be compared to GDP values, pointing out that: 'If GDP increases, some take this to mean that the people in a country are doing better. However, if the Gini index is rising as well, it suggests that the majority of the population may not be experiencing increased income'. In any case, the need for governments to take into account their citizens' desire to improve their well-being and not just their nation's economic prosperity seems to be increasing. ${ }^{5}$

\footnotetext{
${ }^{4}$ This nationalistic and protectionist tendency is particularly evident in times of crisis.

${ }^{5}$ During the coronavirus crisis, a YouGov poll (Youel, 2020) has found that 8 out of 10 people would prefer the British government to prioritise and improve well-being over economic growth. Harvey (2020, May 10) highlights that the 'measures of the UK's quality of life should replace the publication of purely economic indicators', by shifting attention towards more social indicators, such as the environment and QoL, in order to improve more effective policy-making.
} 


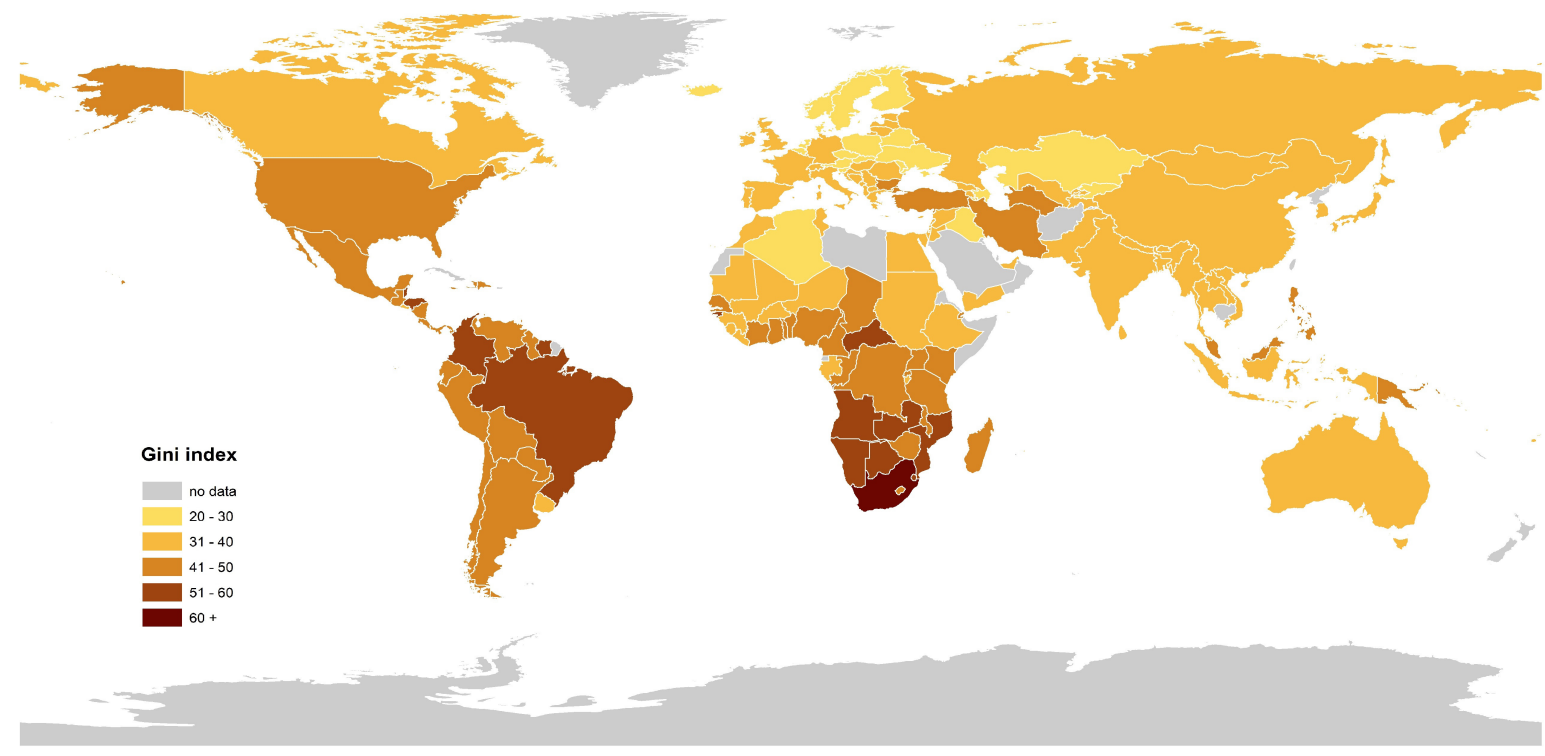

Figure 1. Gini index

Source: author's own elaboration based on World Bank data (WB, 2020) 


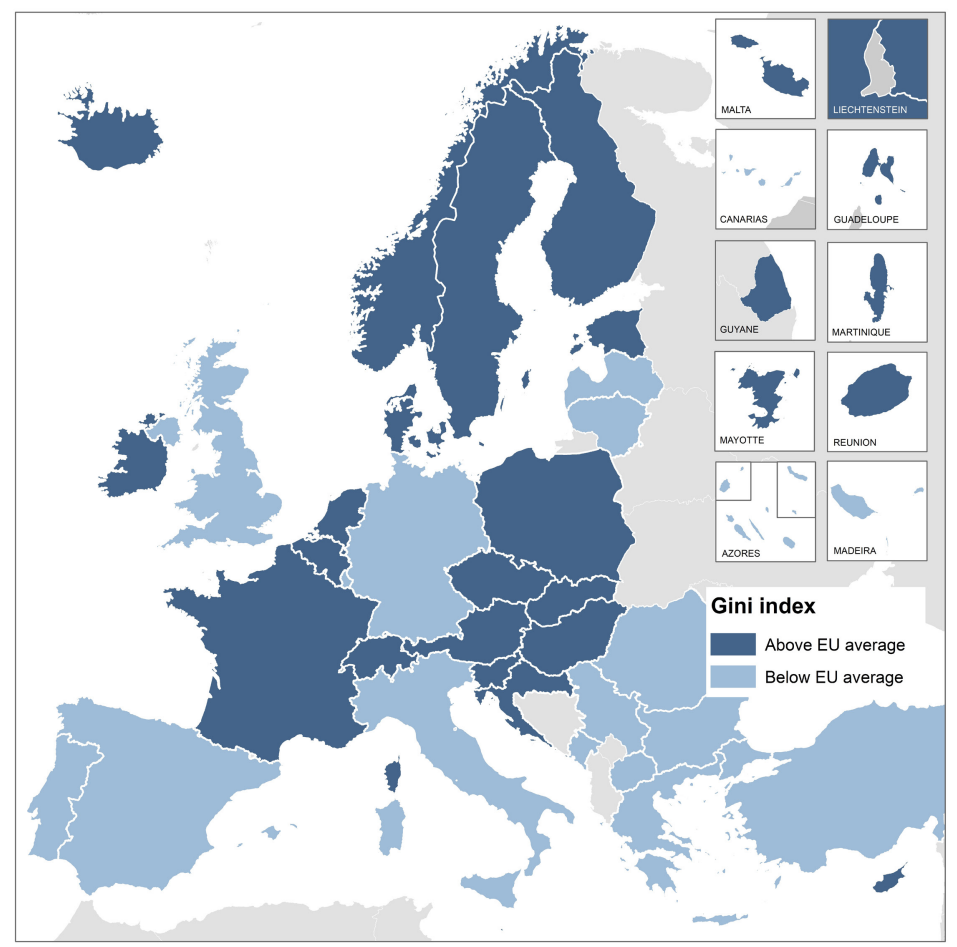

Figure 2. 2018 Gini index

Source: author's own elaboration based on Eurostat data (Eurostat, 2020).

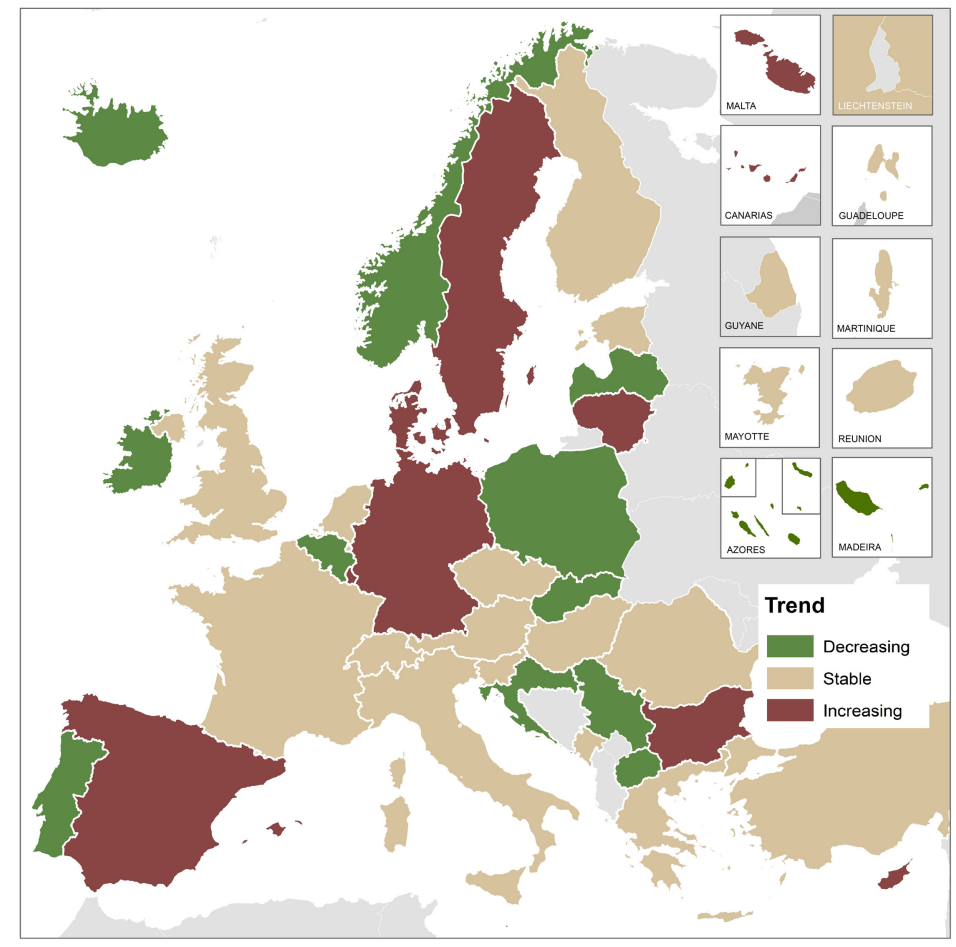

Figure 3. 2005-2019 trend

Source: author's own elaboration based on Eurostat data (Eurostat, 2020). 
Austin (2018) asserts that the equality of well-being, defined in terms of capabilities, provides the strongest, most defensible account of egalitarian social justice, and the foundations of a just society. Moreover, the principle of 'well-being' is often associated with that of 'welfare'; in fact the level of well-being is considered to be higher and more equitably distributed in welfare states (Veenhoven, 2007). However, Veenhoven's comparative research on over 40 countries shows that there does not seem to be a connection between the size of state welfare and well-being equality among citizens. This seems to be confirmed by the figures above, where the Gini index shows higher than expected inequality levels in some Nordic countries, where the state welfare is strong. ${ }^{6}$ Socioeconomic inequality is also seen as one of the 'significant outcomes of the widely used austerity policies that have affected various dimensions of well-being, including income redistribution, employment, and social exclusion - all with local and regional variations' (COHSMO, 2016, p. 6).

\section{Defining spatial justice}

The concepts of 'well-being' and of 'equality' are strongly linked to that of 'spatial justice'. However, an agreed definition of the concept of 'spatial justice' still seems to be missing. As a consequence of this gap, Adegeye and Coetzee $(2019$, p. 388 ) have noted that 'planners trying to achieve spatial justice were unable to incorporate it into their policies and plans' and propose a working definition of the concept. For them, spatial justice can be defined as a 'spatial distribution of socially valued resources such as education, employment, transport, health and housing in any society in such a way that everyone would have adequate access to them, with the disadvantaged of the society being the first beneficiaries rather than last' (p. 388). They also point out that 'in an endeavour to achieve spatial justice, the aforementioned could be incorporated into spatial planning policies, plans, frameworks, and structure of cities by the promotion of diversity, democracy, equity and a just distribution based on merit and/or need' (p. 387). Thus, the adoption of a common definition of spatial justice could become a useful policy framework that could guide local governance institutions. In this way, policies and strategies that aim to reach spatial justice would be more effectively implemented. Overall, it seems that both well-being and spatial justice are objectives that spatial planning should aim to achieve. ${ }^{7}$ Nevertheless, it is important that an agreed definition of both the concepts should be adopted by policy-makers and planners in order to apply these concepts in the development of local policies, strategies and plans.

\section{Resource efficiency and circular economy}

Economic growth is generally presented as 'linear'. Yet, linear economic systems, as for example set out in the GDP surveys, seem to have led to the creation of extreme and precarious forms of inequality. In fact, according to Oxfam (OXFAM, 2018, January 22), the richest 1 per cent of the world's population owns as much as the rest of the world put together. In response, the concept of 'circular economy' has become an important topic of debate in the academic discourse. The Ellen MacArthur Foundation (EMF) sees the circular economy as 'one that is restorative, and one which

\footnotetext{
${ }^{6}$ For a recent overview of equity, (in)equality and participation issues in policy-making processes, see Solly (2020). The paper also focuses on some aspects of spatial planning and territorial governance in Sweden, a country with a strong tradition of social welfare.

7 The promotion of citizens' well-being through the achievement of a wide range of economic, social and environmental objectives traditionally lies at the heart of 'spatial planning's legitimation (see e.g. Healey \& Hillier, 2008; Fainstein, 2010; Barton, 2017). Despite this, in many contexts, spatial planning does not aim to promote well-being and spatial justice. The goal is rather the: i) promotion of economic growth; ii) the allocation of land resources and activities that benefit market players; and iii) the provision of infrastructures and spatial order opposed to socially-oriented goals.
} 
aims to maintain the utility of products, components and materials and retain their value' (EMF, 2015; EEA, 2016). The concept is also believed to enable 'wider economic and social benefits, such as greater well-being, sustainable growth and employment' (WHO, 2018). Thus, the transition towards the circular economy could contribute to the achievement of certain targets of the SDGs, especially as regards well-being -SDG 3 (EMF, 2017). However, the United Nations Industrial Development Organisation (UNIDO) observes that 'while the circular economy takes into account two pillars of sustainability - environmental and economic performance - it risks leaving out an essential third pillar: inclusiveness' (UNIDO, 2017). If inclusiveness aspects are not included within the pillars of the circular economy, the process could exclude many less developed countries with high inequality levels. Nonetheless, according to Schröder (2018, March 19), the 'circular economy can become more inclusive than the linear economy, but this will not happen automatically and requires additional efforts'. Thus, it is important for the circular economy to address long-term equity and inclusiveness aspects. Moreover, Remøy, Wandl, Cerić and van Timmeren (2019, p. 3) argue that, 'incorporating the concept of Circular Economy in an integrative manner in urban design and planning courses is challenging because of its metabolic and complex nature'. In any case, spatial planning is expected to reinforce the shift towards the adoption of a circular economy. ${ }^{8}$ The outcomes of this spatial transition can already be seen in many regions and cities worldwide, which are adopting various long-term programmes and strategies. ${ }^{9}$ Petit-Boix and Leipold (2018, p. 1270) observe that 'cities are implementing a number of initiatives that aim to turn them into sustainable circular systems'; nevertheless, they also note that 'whether these initiatives achieve their sustainability goals, however, is largely unknown'.

\section{QoL and sustainability}

Schäfer, Nölting and Illge $(2004$, p. 1) point out that the concepts of QoL and of sustainability have mostly been treated separately from each other, even though they share many common features, such as dealing with existing and desirable living conditions of human beings. They suggest that a multidimensional approach to QoL is compatible with the normative premises of sustainable development (2004, p. 4). In fact, the concept of sustainability is strongly related to the concept of the QoL of a population: of whether the 'economic, social and environmental systems that make up the community are providing a healthy, productive, meaningful life for all community residents, present and future' (Hart, 2000). Therefore, by exploiting the natural environment and using the existing resources unsustainably, people are directly affecting their well-being (Grünberger \& Omann, 2011, p. 1). However, while the concept of QoL concentrates on the present well-being of people, sustainable development also focuses on the future generations. The 2009 Report by the Commission on the Measurement of Economic Performance and Social Progress has made an important distinction between the assessment of current well-being and that of sustainability, and whether this can last over time. In fact, 'whether these levels of well-being can be sustained over time depends on whether stocks of capital that matter for our lives (natural, physical, human, social) are passed on to future generations' (Stiglitz et al., 2009, p. 11).

Even though not all people and cultures value QoL in the same way, some of the basic issues

\footnotetext{
${ }^{8}$ Nonetheless, the integration of circular economy thinking in planning is currently quite embryonic, even in countries leading on this front like the Netherlands. There are policies and strategies for circular economy, but they are seldom spatial and seldom consider social dimensions, with the focus being on industrial symbiosis and waste management.

${ }^{9}$ For example, rather than relying on a traditional linear urban metabolism that consumes resources and discards waste, the Hammarby Model in Stockholm is a cyclical system that optimises the use of resources and minimises waste (WA, 2020).
} 
taken into consideration when determining QoL include the presence of environmental pollution, the quality of housing and the levels of employment. However, it is 'not possible in many cases to determine whether there are interactions between certain rules of sustainability and of quality of life dimensions, as this largely depends on the way in which certain objectives are achieved' (Schäfer et al., 2004, p. 7). People's lifestyle and personal norms also play an important role and, as Grünberger and Omann (2011, p. 2) argue, adopting a sustainable behaviour not only reduces negative effects on the natural environment, but may lead to an increased subjective well-being. They suggest that consumption patterns may also directly affect people if they become part of the 'treadmill of wanting more and comparing with others' (p. 6), buying as many material goods as possible rather than concentrating on basic goods and the importance of immaterial values, such as art and culture.

\section{The role of spatial planning}

Inequality is strongly related to its spatial dimension. In fact, it seems that cities that provide more public services also provide more equal opportunities, as well as promoting a better standard of living. However, as Simoni (2020, April 18) points out, in the next years inequality levels are projected to increase (especially in a post-COVID-19 scenario) together with the role of cities, which are expected to design and implement more effective policies that aim to reduce urban disparities. As pointed out by a recent tweet of the International Monetary Fund (IMF), ${ }^{10}$ pandemics progressively widen the inequality gap between the rich and poor, as measured by the Gini coefficient. In a future scenario, however, it is also likely that short-term economic policies are going to prioritize future development, at the expense of long-term sustainable growth. Nevertheless, it is also possible that development based uniquely on economic growth might acerbate existing inequalities, especially in urbanized areas. In this regard, Munasinghe (2020) explains that inequality is the most visible effect of unsustainable development; thus, it is likely that there will be an increase of inequality levels in already very unequal and vulnerable contexts (especially in less-developed countries). However, he also argues that neoliberal states are very vulnerable to outside 'shocks' and events. In order to face these issues, it is important to promote a more balanced, resilient and holistic long-term development. In short, 'understanding the nature of the relationship between life satisfaction and individuals' direct environment is an essential question that lies at the core of urban planning policies' (Brown, Oueslati \& Silva, 2015, p. 8).

\section{New challenges}

New challenges are giving rise to a new emphasis on the role of spatial planning. For example, in the next years, more meteorological events that trigger compound coastal flooding are projected. Thus, it is important that suitable measures of adaptation planning are implemented in order to protect coastal communities against future flooding and sea level rise (Bevacqua et al., 2020, p. 1). In Europe, as a consequence of climate change, sea levels could rise by one metre or more by the end of the century and current research emphasizes the urgency of the issue (Vousdoukas et al., 2020). The challenge of surging seas has traditionally been dealt with by the building of barriers (e.g. Thames Barrier in London, MOSE in Venice, the extensive Dutch system of dykes). Many authors now suggest the adoption of the concept of 'managed retreat'. However, Siders, Hino and

\footnotetext{
${ }^{10}$ IMF researchers show that \#pandemics progressively widen gap between rich and poor, as measured by the net Gini coefficient (\#inequality measure) (Furceri, Loungani \& Ostry, 2020, May 11).
} 
Mach (2019, p. 761) argue that managed retreat is mainly focused on risk reduction rather than wider societal objectives, leading to a process that is 'frequently inequitable and often ignores the communities left behind or those receiving people who retreat'. Yet, these communities should be involved in the territorial decision-making process and thus in the spatial planning. Consequently, an innovative approach that combines territorial governance (thus, focusing on social, economic and institutional issues) and climate change long-term effects (thus, environmental issues; e.g. the prospect of climate change causing surging seas and inland flooding) is needed to promote a more equitable and sustainable future development.

There seems to be a close relationship between the achievement of sustainable development and specific institutional mechanisms. Rosati and Faria (2019, p. 1323) point out that organizations reporting on SDGs are usually located in countries with higher levels of climate vulnerability. Therefore, many countries, especially those that face climate change threats (e.g. South Africa), are willing to adopt more effective and long-term sustainable measures and policies, in line with an overarching institutional framework of guiding principles (e.g. 2030 Agenda, European Green Deal).

\section{Contextual factors, evidence from South Africa}

South Africa has among the highest inequality levels worldwide (see Figure 1). These inequality levels would seem to have been exacerbated by the neoliberal turn, which, since the 1990s, has witnessed an 'overaccumulation-crisis displacement' (Bond \& Malikane, 2019, p. 803). This neoliberal shift has also been taking place in many other countries, leading to similar outcomes. In Sweden, for example, the rise of neoliberal values has led to an increase of inequalities in the country since the 1990s (Solly, 2020, p. 8). For Martin, Evans and Karvonen (2018, p. 269), the key to reducing neoliberal forms of urban development and at the same time emphasizing social equity and environmental protection, thus endorsing sustainable development, lies in strengthening citizen empowerment and inclusion.

Nevertheless, in recent years, South Africa has been gradually implementing good practices, as well as adopting strategies in order to promote sustainable development. As a result, the country is in line with the international SDGs, ${ }^{11}$ as can be seen in the adoption of South Africa's first Voluntary National Review (VNR), which supports the implementation of policies that encourage long-term sustainable development. The influence of the international discourse also seems to have reached the local level, where various municipalities have been engaging with the SDG goals. Currently, the UN is strongly supporting local governments and stakeholders, improving 'development coordination $^{\prime 2}$ in order to enhance the capacity of the 2030 Agenda for sustainable development. However, as Pieterse (2019, p. 34) observes, 'the scope and interdependency of the 17 goals reflect the complexity of operationalizing actions within the state and across society to achieve these desired outcomes'.

South Africa is committed to the implementation of the Agenda 2030 and to do this it has created a national coordination mechanism composed of the African Union's Agenda 2063 and the Southern African Development Community's Regional Indicative Strategic Development Plan, in coordination with the National Development Plan (NDP). The South African National Development Plan 2030 proposes that 'spatial justice be applied in all development projects, and how the requirements of spatial justice will be achieved must be indicated' (Adegeye \& Coetzee, 2019, p. 388). It also aims to reduce long-term inequality levels, promoting better living conditions and

\footnotetext{
${ }^{11}$ For more information see: https://sustainabledevelopment.un.org/memberstates/southafrica.

${ }^{12}$ See, for example, https://unsdg.un.org/2020-unsdg-chair-report.
} 
an inclusive economy by 2030. Thus, the NDP is in line with the 2030 Agenda and its goals seem to be integrated into the country's spatial planning system, guiding governance processes at the national, provincial and local levels. However, Francis and Webster $(2019$, p. 800$)$ argue that the country needs good implementation rather than good policy, as 'inequality requires us to think beyond technocratic policy solutions, and beyond a focus on measuring and quantifying inequality, and instead to the ways in which we can harness political, economic and social power for the good society'.

Pieterse $(2019$, p. 34) notes that as a result of the SDGs 'urban governance has been thrust into the spotlight'. In order to manage more effectively urbanisation processes, an Integrated Urban Development Framework (IUFD) has been adopted by the government. The policy initiative also aims to promote more inclusive and liveable urban settlements. For Kollamparambil (2020), happiness inequality is a useful measure of inequality in society. His findings on happiness inequality in South Africa show that, despite an increase of income inequality, the country has been recording a decreased level of happiness inequality. Parry and van Eeden (2015) emphasise the importance of the interconnection between equality and well-being, arguing that residential segregation in post-apartheid South Africa might now be intrinsically linked to economic well-being. For them, this 'suggests that any attempts to improve integration through the design of urban space might not yield any positive results until the larger problem of economic inequality has been addressed' (p. 47). Nevertheless, the country seems to be well placed towards reaching the objectives of the Agenda 2030, through the implementation of the seventeen SDGs.

\section{Contextual factors, evidence from the UK}

As observed above, inequality levels are high in many European countries. However, differences among various European cities and regions can be observed. For example, as regards wealth inequality, London presents higher inequality levels than the UK national level. This can be seen in a higher proportion of households both at the bottom and at the top of wealth distribution compared to the rest of the country (LD, 2020). These values also seem to be confirmed by the recently launched OECD online platform that measures the distance towards the SDGs in a number of regions and cities (OECD, 2020). ${ }^{13}$ According to the OECD platform, the Greater London county inequality values (SDG 10) rank lower (57) when compared to the country average (83), as well as to the overall OECD average (77). Interestingly, Greater London's well-being values (SDG 4) rank higher (100) than the UK country average (91), as well as the OECD average (59). Another interesting value is SDG 11 (sustainable cities and communities): Greater London ranks much higher (90) than the OECD country average (73); nevertheless, the UK country average ranks even higher (98). Thus, even if certain SGD targets still have lower values (e.g. inequality levels), both Greater London and the overall UK seem to be well placed towards reaching long-term sustainable development, in line with the objectives of the Agenda 2030.

Since 2015, many cities and regions, both in Europe and beyond, have been endorsing the principles of long-term sustainable development, in line with the Agenda 2030. Many have also been supporting the shift towards a circular economy, encouraging the concepts of 'resource efficiency', 'renewables' and of 'reuse'. In fact, according to Girard and Nocca (2019, p. 47), the circular economy model can be 'implemented in cities in order to operationalize and achieve human sustainable development managing simultaneously, in a systemic perspective, the social inequalities issue and

\footnotetext{
${ }^{13}$ The purpose of the platform is to foster policy dialogue and the exchange of know-how across regions and cities, as well as increase awareness of the SDGs across society. In fact, the OECD argues that effective coordination and engagement is needed across subnational governments (regional and local) in order to meet the targets of the SDGs.
} 
the ecological and economic crisis'. Therefore, the circular economy seems to contribute to the implementation of sustainable development, contributing to the implementation of various SDGs. Consequently, many European cities and regions have been adopting policies and strategies in order to shift their economic systems towards a circular economy. The city of Brussels, for example, is transforming circular economy principles into urban planning. This can be seen in the Be Circular programme (BC, 2020), an initiative promoted by the government of the Brussels-Capital region, within the framework of the Circular Economy regional programme (Programme Régional en Economie Circulaire, PREC). The City of Paris is also committed to the principles of circular economy and in 2017 has adopted a Circular Economy Plan (PÉC, 2019). In Italy, the 'Circular Index' indicates that the country has a high level of commitment to circular economy principles. In fact, it ranks among the five main European economies that are promoting a more efficient use of resources. However, the 2020 Italian National report on the circular economy (Rapporto nazionale sull'economia circolare; RSC, 2020) reports that the country's circular economy is slowing down.

In London, the circular economy concept has been adopted and integrated in the regeneration development of the 'Old Oak and Park Royal Districts' (OPDC, 2020a), a new 650 hectare site of residential and industrial area in west London. It formally came into being with the establishment of the Old Oak and Park Royal Development Corporation (OPDC) by the Mayor of London on 1 April $2015 .{ }^{14}$ A Local Plan has been drafted, setting out the vision of how the area will develop over the next twenty years, complete with a new railway station. The local stakeholders have been involved in the project since the setup of the project. In fact, three rounds of public consultation with the local community, involving both public and private actors, have led to over 11,000 comments. The comments generated during the public consultation process (the first held in 2016) have been used to strengthen the development of the Local Plan. In 2018, the Local Plan was submitted to the Planning Inspectorate for independent examination. If the Planning Inspector accepts the Local Plan, it will become legally binding, guiding the future development of the area. ${ }^{15}$ Once in operation, approximately 250,000 passengers are expected to be using the Old Oak Common Station every day, so it is likely to become one of the busiest stations in the country. In order to maximise its connectivity, the station envisages an integration with public transport facilities, as well as pedestrian and cycle lanes. Thus, the OPDC is working in synergy with the HS2 and Elizabeth line rail infrastructure projects, in order to create new opportunities in the area. It also aims to ensure long-term sustainable development and the environmental, economic and social resilience of the neighbourhood. To do this, the project applies the principles of circular economy and ensures an efficient circulation and reuse of local resources and materials (e.g. water, heat).

The preliminary draft of the local plan (OPDC, 2018) for the regeneration of the Old Oak and Park Royal districts incorporates the concepts of circular economy. The OPDC has developed a Circular and Sharing Economy Study (OPDC, 2020b), which has identified specific measures (e.g. resource efficiency) in order to guide more effectively the policies of the plan. In particular, the draft of the local plan includes various 'policy links'. Within the 'Environment and Utilities Chapter', which provides specific policies that are in line with the Mayor's London Plan and London Environmental Strategy, section 'EU7' focuses on the 'Circular and Sharing Economy' and integrates the policy recommendations identified by the Circular and Sharing Economy Study. ${ }^{16}$ Interestingly, the

\footnotetext{
$\overline{14}$ The transformation of the former railway and industrial site is recognised as one of the largest regeneration projects in Europe. The plan envisages the creation of more than 25,500 new homes and 65,000 jobs.

15 On 19 May 2020, the HS2 (High Speed 2) Old Oak Common Station design was approved.

16 The plan requires all major development proposals to submit a Circular and Sharing Economy Statement, indicating how sharing economy principles have been adopted in the development process. Therefore, all development proposals must incorporate and implement the principles of the circular and sharing economy, such
} 
plan also enhances the use of 'communal space', as well as local food production projects (e.g. urban farming initiatives, food waste could be reused to produce energy). If these policy aspects are correctly implemented in the overall strategy, they could support a transition towards a more circular economy, as well as promote long-term sustainable development. The regeneration of the Old Oak and Royal Park area is therefore expected to bring significant benefits to the local community. In fact, the project states that it aims to improve the environmental social and economic well-being of its citizens and also to reduce health inequalities, enhancing the overall QoL of the local people.

\section{Considerations and conclusions}

In 2015, Secretary-General Ban Ki-moon of the United Nations, observed that:

Our world is under strain. Poverty continues to plague communities and families. Climate change threatens livelihoods. Conflicts are raging. Inequalities are deepening. These crises will only worsen unless we change course. That is why world leaders are hard at work on a new development agenda - including a set of concrete sustainable development goals - to help guide humanity to safety and prosperity (2015, p. xi).

Poverty, climate change, conflicts and inequalities are still rife in much of the world and currently inequality levels seem to be on the rise in many cities and regions. There is, therefore, a strong need to create and implement more effective policies that enhance social justice, reducing social, environmental and economic disparities, and thus making the playing field more level. As we have seen, inequality is strongly related to its spatial dimension and for Munasinghe (2020) it is one of the most visible outcomes of unsustainable development. At present, many cities are promoting the transformation into 'sustainable cities and communities' (SDG 11), in order to promote long-term sustainable development. For example, London, seems to be overall well-placed towards achieving its long-term SDGs. To achieve them, the city is promoting its transformation into a sustainable city and community. This process has been leading to the creation of various regeneration projects, such as the Old Oak and Royal Park site discussed above. Nevertheless, the city still seems to rank high as regards inequality levels, highlighting the need for these issues to be addressed more effectively in local policies and projects. So, even if many cities seem to be in line with the aims and objectives of the Agenda 2030, local communities must increase their commitment and willingness to promote and achieve long-term sustainable growth, as well as to reduce inequality gaps (especially in already vulnerable areas) and engage with new challenges and new approaches.

Furthermore, since there is an important interrelationship between the built environment and the well-being of people, it is essential for urban planning policies to adopt more effective research-based policies that will trigger and drive sustainable and equitable development over time. Thus, urban planning policies should aim to achieve higher levels of well-being and of sustainability. Indeed, the concepts of QoL and sustainability share many common features and should be treated in a more integrated way, thereby endorsing the notion of sustainable well-being. Finally, it is important to promote a more balanced and holistic long-term sustainable and equitable development, enhancing a more effective (re)use of local resources. In fact, adopting policies which enhance economic objectives (e.g. smart growth), but that ignore environmental (e.g. sustainable growth) and social (e.g. inclusive growth) objectives, could likely lead to an increase in social disparities and environmental degradation, and therefore reduce people's overall well-being.

as the use of renewable and low carbon energy and of sustainable mobility (e.g. walking and cycle lanes). 


\section{References}

Adegeye, A., \& Coetzee, J. (2019). Exploring the fragments of spatial justice and its relevance for the global south. Development Southern Africa, 36(3), 376-389. https://doi.org/10.1080/037683 5X.2018.1495062

Ahlfeldt, G. M., \& Pietrostefani, E. (2019). The economic effects of density: A synthesis. Journal of Urban Economics, 111, 93-107. https://doi.org/10.1016/j.jue.2019.04.006

Allmendinger, P., Haughton, G., Knieling, J., \& Othengrafen, F. (2015). Soft Spaces in Europe: Re-negotiating governance, boundaries and borders. London: Routledge.

Arrow, K. J., Cline, W. R., Mäler, K-G., Munasinghe, M., \& Stiglitz, J. E. (1995). Intertemporal equity and discounting. In M., Munasinghe (Ed.). Global Climate Change: Economic and Policy Issues (pp. 1-32). Washington, DC: World Bank.

Austin, A. (2018). Well-Being and Social Justice: In Defence of the Capabilities Approach. In] I., Bache \& K., Scott (Eds.). The Politics of Wellbeing: Theory, Policy and Practice (pp. 49-70). Cham: Palgrave Macmillan.

Barton, H. (2017). City of Well-Being. A Radical Guide to Planning. London, New York, NY: Routledge. https://doi.org/10.4324/9781315438689

BC (2020). Be Circular. Retrieved from http://circulareconomy.brussels/chronologie/

Beramendi, P. (2007). Inequality and the Territorial Fragmentation of Solidarity. International Organization, 61(4), 783-820. https://doi.org/10.1017/S0020818307070270

Bevacqua, E., Vousdoukas, M. I., Zappa, G., Hodges, K., Shepherd, T. G., Maraun, D., Mentaschi, L., \& Feyen, L. (2020). More meteorological events that drive compound coastal flooding are projected under climate change. Communications Earth \& Environment, 1, 47. https://doi.org/10.1038/ s43247-020-00044-z

Berisha, E., Cotella, G., \& Solly, A. (Eds.) (forthcoming). Governing territorial development in the Western Balkans. Challenges and prospects of regional cooperation. New York, NY: Springer.

Bond, P., \& Malikane, C. (2019). Inequality caused by macroeconomic policies during overaccumulation crisis. Development Southern Africa, 36(6), 803-820. https://doi.org/10.1080/037683 5X.2019.1701416

Brown, Z. S., Oueslati, W., \& Silva, J. (2015). Exploring the Effect of Urban Structure on Individual Well-Being. OECD Environment Working Papers, 95. Paris: OECD Publishing.

Brueckner, J. K. (2006). Government Land-Use Interventions: An Economic Analysis. Urban Research Symposium. Washington DC: World Bank.

Buttrick, N. R., Heinzelman, S. J., \& Oishi, S. (2017). Inequality and well-being. Current Opinion in Psychology, 18, 15-20. https://doi.org/10.1016/j.copsyc.2017.07.016

Carmin, J., \& Agyeman, J. (2011). Environmental Inequalities Beyond Borders. Local Perspectives on Global Injustices. Cambridge, MA: MIT Press.

Carmona, M., \& Sieh, L. (2004). Measuring Quality in Planning, Managing the Performance Process. London: Spon Press.

Čeperković, M., \& Gaub, F. (2018). Balkan futures: Three scenarios for 2025. Chaillot Paper, 147, European Union Institute for Security Studies. Retrieved from https://www.iss.europa.eu/content/balkan-futures-three-scenarios-2025

Cheshire, P., \& Vermeulen, W. (2009). Land Markets and their Regulation: The Economic Impacts of Planning. In H. S., Geyer (Ed.). International Handbook of Urban Policy (vol. 2). Cheltenham: Edward Elgar.

COHSMO (2016). Policy Brief 1. Inequality, urbanization and Territorial Cohesion: Developing the European Social Model of economic growth and democratic capacity. Retrieved from https://www.cohsmo. aau.dk/wp-content/uploads/2018/12/COHSMO-Policy-Brief-no.-1.pdf

EEA (2016). Circular economy in Europe: developing the knowledge base. Copenhagen: European Environment Agency. Retrieved from https://www.eea.europa.eu/publications/circular-economy-in-europe

EMF (2015). Delivering the circular economy: a toolkit for policy-makers. Cowes: Ellen MacArthur Foundation. Retrieved from https://www.ellenmacarthurfoundation.org/publications/delivering-the-circular-economy-a-toolkit-for-policymakers 
EMF (2017). Achieving growth within: a €320-billion circular economy investment opportunity available to Europe up to 2025. Cowes: Ellen MacArthur Foundation and SYSTEMIQ. Retrieved from https:// www.ellenmacarthurfoundation.org/publications/achieving-growth-within

ESPON SUPER (2020). ESPON SUPER - Sustainable Urbanisation and land-use Practices in European Regions. A Guide to Sustainable Urbanisation and Land-Use. Luxembourg: ESPON EGTC. Retrieved from https://www.espon.eu/sites/default/files/attachments/2020_ESPON_SUPER_Guide_final_ A4_screenview.pdf

Eurostat (2020). Eurostat database. Retrieved from https://ec.europa.eu/eurostat/data/database

Ezcurra, R., \& Rodríguez-Pose, A. (2014). Government Quality and Spatial Inequality: A Cross-Country Analysis. Environment and Planning A: Economy and Space, 46, 1732-1753. https://doi.org/10.1068/ a13\%0046p

Fainstein, S. (2010). The Just City. Ithaca, NY: Cornell University Press. https://doi.org/10.1007/s10901011-9243-8

Francis, D., \& Webster, E. (2019). Poverty and inequality in South Africa: critical reflections. Development Southern Africa, 36(6), 788-802. https://doi.org/10.1080/0376835X.2019.1666703

Furceri, D., Loungani, P., \& Ostry, J. D. (2020, May 11). How Pandemics Leave the Poor Even Farther Behind. IMFBlog. Retrieved from https://blogs.imf.org/2020/05/11/how-pandemics-leave-the-pooreven-farther-behind/

Ganić, M. (2019). The Labour Market, Social Inequality and the Role of Emigration: The Case of the Western Balkan Economies. In R., Osbild \& W., Bartlett (Eds.). Western Balkan Economies in Transition: Recent Economic and Social Developments (pp. 61-72). Cham: Springer. https://doi.org/10.1007/9783-319-93665-9_5

Girard, L. F., \& Nocca, F. (2019). Moving Towards the Circular Economy/City Model: Which Tools for Operationalizing This Model? Sustainability, 11(22), 6253. https://doi.org/10.3390/su11226253

Grünberger, S., \& Omann, I. (2011). Quality of Life and Sustainability. Links between sustainable behaviour, social capital and well-being. Paper presented at 9th Conference of the European Society for Ecological Economics held in Istanbul 14-17 June 2011.

Hart, M. (2000). Sustainable Measures: What is Sustainability, anyway? (2nd ed.). North Andover, MA: Sustainable Measures.

Harvey, F. (2020, May 10). Britons want quality of life indicators to take priority over economy. The Guardian. Retrieved from https://www.theguardian.com/society/2020/may/10/britons-want-quality-of-life-indicators-priority-over-economy-coronavirus

Healey, P., \& Hillier, J. (2008). Critical Essays in Planning Theory. Aldershot: Ashgate.

Ihlanfeldt, K. R. (2005). The Effect of Land Use Regulation on Housing and Land Prices. Journal of Urban Economics, 61, 420-435. https://doi.org/10.1016/j.jue.2006.09.003

Ki-moon, B. (2015). Foreword. In J. D., Sachs (Ed.). The Age of Sustainable Development (pp. xi-xii). New York, NY: Columbia University Press.

Kollamparambil, U. (2020). Happiness, Happiness Inequality and Income Dynamics in South Africa. Journal of Happiness Studies, 21, 201-222. https://doi.org/10.1007/s10902-019-00075-0

LD (2020). Economic Fairness. London Datastore. Retrieved from https://data.Iondon.gov.uk/economic-fairness/equal-opportunities/wealth-inequality/\#: :text=The\%20households\% 20in\%20London\%20that,cent\%20of\%20the\%20total\%20wealth

Martin, C., Evans, J., \& Karvonen, A. (2018). Smart and sustainable? Five tensions in the visions and practices of the smart-sustainable city in Europe and North America. Technological Forecasting and Social Change, 133, 269-278. https://doi.org/10.1016/j.techfore.2018.01.005

Milanovic, B. (2016). Global Inequality: A New Approach for the Age of Globalization. Cambridge, MA: Harvard University Press.

Moroni, S. (2010). An evolutionary theory of institutions and a dynamic approach to reform. Planning Theory, 9(4), 275-297.

Munasinghe, M. (2020). Sustainability after COVID-19: Public policies for inclusive green growth. Webinar organised by the Green Growth Knowledge Partnership, 28 April 2020. Retrieved from https:// www.greengrowthknowledge.org/learning/ggkp-webinar-sustainability-after-covid-19-public-policie s-inclusive-green-growth 
OECD (2012). OECD Environmental Outlook to 2050: The Consequences of Inaction. Paris: OECD Publishing. https://dx.doi.org/10.1787/9789264122246-en

OECD (2014). Focus on Inequality and Growth. Paris: OECD Publishing. Retrieved from https://www. oecd.org/social/Focus-Inequality-and-Growth-2014.pdf

OECD (2015, April 26). Growth and income inequality: trends and policy implications. Paris: OECD Economics Department Policy Notes. Retrieved from http://search.oecd.org/economy/labour/ Growth-and-income-inequality-trends-and-policy-implications.pdf

OECD (2020). Measuring the distance to the SDGs in regions and cities. Retrieved from https://www. oecd-local-sdgs.org/index.html

OPDC (2018). Local Plan 2018. Old Oak and Park Royal Development Corporation. Retrieved from https://www.london.gov.uk/sites/default/files/opdc_local_plan_2018.pdf

OPDC (2020a). Introduction to the Old Oak and Park Royal Development Corporation. Old Oak and Park Royal Development Corporation. Retrieved from https://www.london.gov.uk/about-us/organisations-we-work/old-oak-and-park-royal-development-corporation-opdc/about-us/introduction-old-oak-and-park-royal-development-corporation

OPDC (2020b). Circular and Sharing Economy Study. Old Oak and Park Royal Development Corporation. Retrieved from https://www.london.gov.uk/sites/default/files/9._circular_and_sharing_economy_ study.pdf

Osbild, R., \& Bartlett, W. (2019). Western Balkan Economies in Transition: Recent Economic and Social Developments. Cham: Springer. https://doi.org/10.1007/978-3-319-93665-9

OXFAM (2018, January 22). Richest 1 percent bagged 82 percent of wealth created last year - poorest half of humanity got nothing. OXFAM International. Retrieved from https://www.oxfam.org/en/press-releases/richest-1-percent-bagged-82-percent-wealth-created-last-year-poorest-half-humanity

$\emptyset$ stby, G., Nordrås, R., \& Rød, J. K. (2009). Regional Inequalities and Civil Conflict in Sub-Saharan Africa. International Studies Quarterly, 53(2), 301-324. https://doi.org/10.1111/j.1468-2478.2009.00535.x

Parry, K., \& van Eeden, A. (2015). Measuring racial residential segregation at different geographic scales in Cape Town and Johannesburg. South African Geographical Journal, 97(1), 31-49. https://doi.org/ 10.1080/03736245.2014.924868

PÉC (2019). Plan Économie Circulairie de Paris. Bilan 2017-2018. Retrieved from https://www.api-site. paris.fr/paris/public/2019\%2F2\%2FEconomiecirculairebilan2017-2018.pdf

Pere, E., \& Bartlett, E. (2019). On the Way to Europe: Economic and Social Developments in Albania. In R., Osbild \& W., Bartlett (Eds.). Western Balkan Economies in Transition: Recent Economic and Social Developments (pp. 73-87). Cham: Springer. https://doi.org/10.1007/978-3-319-93665-9_6

Petit-Boix, A., \& Leipold, S. (2018). Circular economy in cities: Reviewing how environmental research aligns with local practices. Journal of Cleaner Production, 195, 1270-1281. https://doi.org/10.1016/j. jclepro.2018.05.\%281

Pieterse, E. (2019). Urban governance and spatial transformation ambitions in Johannesburg. Journal of Urban Affairs, 41(1), 20-38. https://doi.org/10.1080/07352166.2017.1305807

Piketty, T. (2014). Capital in the Twenty-First Century. Cambridge, MA: Belknap Press.

Quigley, J. M., \& Rosenthal, L. A. (2005). The Effects of Land-Use Regulation on the Price of Housing: What Do We Know? What Can We Learn? Cityscape: A Journal of Policy Development and Research, 8(1), 69-138.

Remøy, H., Wandl, A., Cerić, D., \& van Timmeren, A. (2019). Facilitating Circular Economy in Urban Planning. Urban Planning, 4(3), 1-4. https://doi.org/10.17645/up.v4i3.2484

Rosati, F., \& Faria, L. C. D. (2019). Addressing the SDGs in sustainability reports: The relationship with institutional factors. Journal of Cleaner Production, 215, 1312-1326. https://doi.org/10.1016/j.jclepro.2018.1\%2.107

RSC (2020). Rapporto nazionale sull'economia circolare. Retrieved from https://circulareconomynetwork.it/wp-content/uploads/2020/04/Rapporto-sulleconomia-circolare-in-Italia-2020_r04 .pdf

Sachs, J. D. (2015). The Age of Sustainable Development. New York, NY: Columbia University Press.

Schäfer, M., Nölting, B., \& Illge, L. (2004). Bringing Together the Concepts of Quality of Life and Sustainability. In W., Glatzer, S., von Below \& M., Stoffregen (Eds.). Challenges for Quality of Life in the Contemporary World (pp. 33-43). Dordbrecht: Kluwer. 
Scheidel, W. (2018). The Great Leveler: Violence and the History of Inequality from the Stone Age to the Twenty-first Century. Princeton, NJ: Princeton University Press.

Schröder, P. (2018, March 19). Can the circular economy design out inequality as well as waste? Retrieved from https://www.ids.ac.uk/opinions/can-the-circular-economy-design-out-inequality-aswell-as-waste/

Sellers, J. M. (2017). Metropolitan Inequality and Governance: A Framework for Global Comparison. In J. M., Sellers, M., Arretche, D., Kübler \& E., Razin (Eds.). Inequality and Governance in the Metropolis: Place Equality Regimes and Fiscal Choices in Eleven Counties (pp. 1-23). London: Palgrave Macmillan.

Siders, A. R., Hino, M., \& Mach, K. J. (2019). The case for strategic and managed climate retreat. Science, 365(6455), 761-763. https://doi.org/10.1126/science.aax8346

Simoni, M. (2020, April 18) Poverty and Inequality. The Role of Cities in a Post-Covid-19 Scenario. Retrieved from https://www.ispionline.it/it/pubblicazione/poverty-and-inequality-role-cities-post-covid-19-scenario-25810

Smith, L. (2020, February 3). The Gini Index: Measuring Income Distribution. Investopedia. Retrieved from https://www. investopedia.com/articles/economics/08/gini-index.asp

Solly, A. (2020). Land use challenges, sustainability and the spatial planning balancing act: insights from Sweden and Switzerland. European Planning Studies. https://doi.org/10.1080/09654313.2020.176 5992

Stiglitz, J. E., Sen, A., \& Fitoussi, J-P. (2009). Report by the Commission on the Measurement of Economic Performance and Social Progress. Paris: Commission on the Measurement of Economic Performance and Social Progress. Retrieved from https://www.economie.gouv.fr/files/finances/presse/dossiers_ de_presse/090914mesure_perf_eco_progres_social/synthese_ang.pdf

TA2030 (2020). Territorial Agenda 2030. A future for all places. Retrieved from https://www.territorial-agenda.eu/home.htm

UN (2015). Transforming our world: the 2030 Agenda for Sustainable Development. Resolution adopted by the General Assembly on 25 September 2015, A/RES/70/1. United Nations. Retrieved from https://www.un.org/ga/search/view_doc.asp?symbol=A/RES/70/1\&Lang=E

UNIDO (2017). Circular Economy. Vienna: United Nations Industrial Development Organization. Retrieved from https://www.unido.org/sites/default/files/2017-10/Circular_Economy_UNIDO.pdf

Veenhoven, R. (2007). Well-being in the welfare state: Level not higher, distribution not more equitable. Journal of Comparative Policy Analysis: Research and Practice, 2(1), 91-125. https://doi. org/10.1080/13876980008412637

Vousdoukas, M. I., Mentaschi, L., Hinkel, J., Ward, P. J., Mongelli, I., Ciscar, J-C., \& Feyen, L. (2020). Economic motivation for raising coastal flood defenses in Europe. Nature Communications, 11, 2119. https://doi.org/10.1038/s41467-020-15665-3

WA (2020). Hammarby Sjöstad regeneration. White Arkitekter. https://whitearkitekter.com/project/ hammarby-sjostad/

WB (2020). World Bank Open Data. Retrieved from https://data.worldbank.org/

WHO (2018). Circular Economy and Health: Opportunities and Risks. Copenhagen: World Health Organization Regional Office for Europe. Retrieved from http://www.euro.who.int/_data/assets/ pdf_file/0004/374917/Circular-Economy_EN_WHO_web_august-2018.pdf?u a=1

Youel S. (2020). New polling: only $12 \%$ want UK to prioritise economic growth over wellbeing. Positive Money. Retrieved from https://positivemoney.org/2020/05/new-polling-only-12-want-uk-to-prioritise-economic-growth-over-wellbeing/ 